УДК 338.2

\title{
ОСОБЛИВОСТІ ОБЛІКУ РОЗРАХУНКІВ ЗА ПОДАТКАМИ В АГРАРНИХ ПІДПРИЕМСТВАХ
}

\section{PECULIARITIES OF ACCOUNTING OF TAX SETTLEMENTS IN AGRICULTURAL ENTERPRISES}

\author{
Чернецька Ольга Віталіївна \\ кандидат економічних наук, доцент, \\ Дніпровський державний аграрно-економічний університет \\ ORCID: https://orcid.org/0000-0002-4691-636X \\ Міньковська Альона Вікторівна \\ кандидат економічних наук, доцент, \\ Дніпровський державний аграрно-економічний університет \\ ORCID: https://orcid.org/0000-0002-9414-4210 \\ Атамас Олександр Петрович \\ кандидат економічних наук, доцент, \\ Дніпровський державний аграрно-економічний університет \\ ORCID: https://orcid.org/0000-0002-7511-8586

\section{Chernetska Olha, Minkovska Alona, Atamas Aleksandr Dnipro State Agrarian and Economic University}

\begin{abstract}
У статті проаналізовано особливості обліку розрахунків за податками в аграрних підприємствах. Наголошено на вимогах до інформаційного забезпечення господарських операцій в частині оподаткування, акцентовано увагу на важливості документального та облікового забезпечення розрахунків за податками в системі менеджменту аграрних підприємств. Розкрито сутність та особливості спрощеної системи оподаткування, наведено вимоги до суб'єктів господарювання в частині єдиного податку IV групи, зазначено ставки єдиного податку IV групи. Відображено порядок облікового забезпечення розрахунків за єдиним податком в аграрних підприємствах. Виокремлено особливості оподаткування податком на додану вартість, наведено ставки податку на додану вартість за окремими товарними позиціями сільськогосподарської продукції, акцентовано увагу на порядку складання податкової накладної, зазначено порядок облікового забезпечення розрахунків за податком на додану вартість.
\end{abstract}

Ключові слова: облік, розрахунки, податки, аграрні підприємства, єдиний податок, податок на додану вартість.

В статье проанализированы особенности учета расчетов по налогам в аграрных предприятиях. Отмечены требования к информационному обеспечению хозяйственных операций относительно налогообложения, акцентировано внимание на важности документального и учетного обеспечения расчетов по налогам в системе менеджмента аграрных предприятий. Раскрыты сущность и особенности упрощенной системы налогообложения, приведены требования к субъектам хозяйствования относительно единого налога IV группы, указаны ставки единого налога IV группы. Отражен порядок учетного обеспечения расчетов по единому налогу в аграрных предприятиях. Выделены особенности налогообложения налогом на добавленную стоимость, приведены ставки налога на добавленную стоимость по отдельным товарным позициям сельскохозяйственной продукции, акцентировано внимание на порядке составления налоговой накладной, указан порядок учетного обеспечения расчетов по налогу на добавленную стоимость.

Ключевые слова: учет, расчеты, налоги, аграрные предприятия, единый налог, налог на добавленную стоимость.

The agricultural sector of the economy has specific economic conditions, which determines the need for state support for commodity production and the introduction of a separate type of taxation of the agricultural sector therefore agricultural enterprises have certain features in calculating taxes. The purpose of the article is to highlight the features of tax calculations in agricultural enterprises and to study the procedure for their reflection in documentation 
and accounting support for the activities of agricultural enterprises. The methodological basis of the research is general scientific and special methods of cognition in particular methods of observation, theoretical generalization and grouping are used. Tabular and graphical methods are used for visual representation of data. The article analyzes the features of accounting for tax calculations in agricultural enterprises. The requirements for information support of business operations in terms of taxation are emphasized, and attention is focused on the importance of documentary and accounting support for tax calculations in the management system of agricultural enterprises. The essence and features of the simplified taxation system are revealed, the requirements for business entities regarding the single tax of group IV are given, and the list of agricultural producers who cannot be payers of the single tax of the fourth group is given. The single tax rates of group IV are indicated, the calculation procedure and base for taxation, the terms and amounts of payment of the single tax in agricultural enterprises are disclosed. Attention is focused on the procedure for cancelling registration as a single tax payer and switching to the general tax system. The procedure for accounting for single tax payments in agricultural enterprises is reflected. Features of value-added tax taxation are highlighted, and tax rates are given value added for individual product items attention is focused on the procedure for drawing up a tax invoice with the allocation of appropriate tax rates, and the procedure for accounting for tax calculations is indicated for added value. The highlighted features of accounting for tax calculations should become the basis for building an effective management system and developing directions for optimizing the tax burden in agricultural production.

Keywords: accounting, calculations, taxes, agricultural enterprises, single tax, value added tax.

Постановка проблеми в загальному вигляді. Аграрна галузь економіки має специфрічні умови господарювання, зокрема, використання в процесі виробництва живих організмів та землі в умовах впливу природних фракторів, що, в свою чергу, зумовлює необхідність державної підтримки товаровиробництва в умовах ринкової економіки. Сучасна податкова система України має достатньо нестабільний та складний характер, що є негативним чинником щодо розвитку аграрного виробництва. Отже, зазначені умови процесу оподаткування аграрної галузі спричиняють певні особливості розрахунків за податками аграрних підприємств. Інформаційне забезпечення господарських операцій в частині оподаткування має бути якісним, оперативним та ефективним, тому документальне та облікове забезпечення розрахунків за податками має надважливе значення в системі менеджменту аграрних підприємств.

Аналіз останніх досліджень і публікацій. Процес оподаткування аграрних товаровиробників завжди викликав жвавий інтерес науковців. Зокрема, вченими Бурковською А. В. та Шкапоєдом В. К визначено особливості та окреслено основні проблеми оподаткування аграрних підприємств в Україні [1]; Колеснік Я. В. та Ніколаєнко А. В. досліджували наслідки підвищення податкового тягаря для платників IV групи єдиного податку [2]; Новак Н. П., Коваль С. В., Круковська О. В. [5] здійснювали пошук шляхів впровадження світового досвіду податкової підтримки малих і середніх сільськогосподарських підприємств. Відзначимо, що праці вищезазначених вчених спрямовані на виокремлення особливостей системи оподаткування, які відповідним чином зумовлюють специфріку документаль- ного і облікового забезпечення розрахунків за податками аграрних підприємств, що становить актуальність дослідження.

Мета статті - виокремити особливості розрахунків за податками в аграрних підприємствах та дослідити порядок їх відображення в документальному офрормленні та обліковому забезпечення діяльності аграрних підприємств.

Виклад основного матеріалу. Для суб'єктів аграрного виробництва передбачено можливість перебування на спрощеній системі оподаткування. Станом на 2021 рік платниками єдиного податку IV групи можуть виступати як юридичні особи так і фрізичні особи - підприємці за умови відповідності певним критеріям. Платником єдиного податку може бути юридична особа будь-якої організаційно-правової форми, в яких частка сільськогосподарського товаровиробництва за попередній податковий (звітний) рік дорівнює або перевищує $75 \%$. До фрізичних осіб - підприємців, а саме фрермерських господарств, які зареєстровані та діють відповідно до Закону України «Про фрермерське господарство», також висуваються умови виконання сукупності вимог (рис. 1).

Відповідно до норм Податкового кодексу [6] $€$ певні заборони щодо перебування на єдиному податку IV групи для окремих суб'єктів господарювання, зокрема для тих, в кого: понад 50 відсотків доходу становить реалізація декоративних рослин, диких тварин і птахів, хутряних виробів і хутра; якщо здійснюється діяльність 3 виробництва і реалізації підакцизних товарів (окрім кодів УКТ ЗЕД 2204 29, 2204 30); якщо існує податковий борг станом на 1 січня (за винятком фрорс-мажорних обставин). 


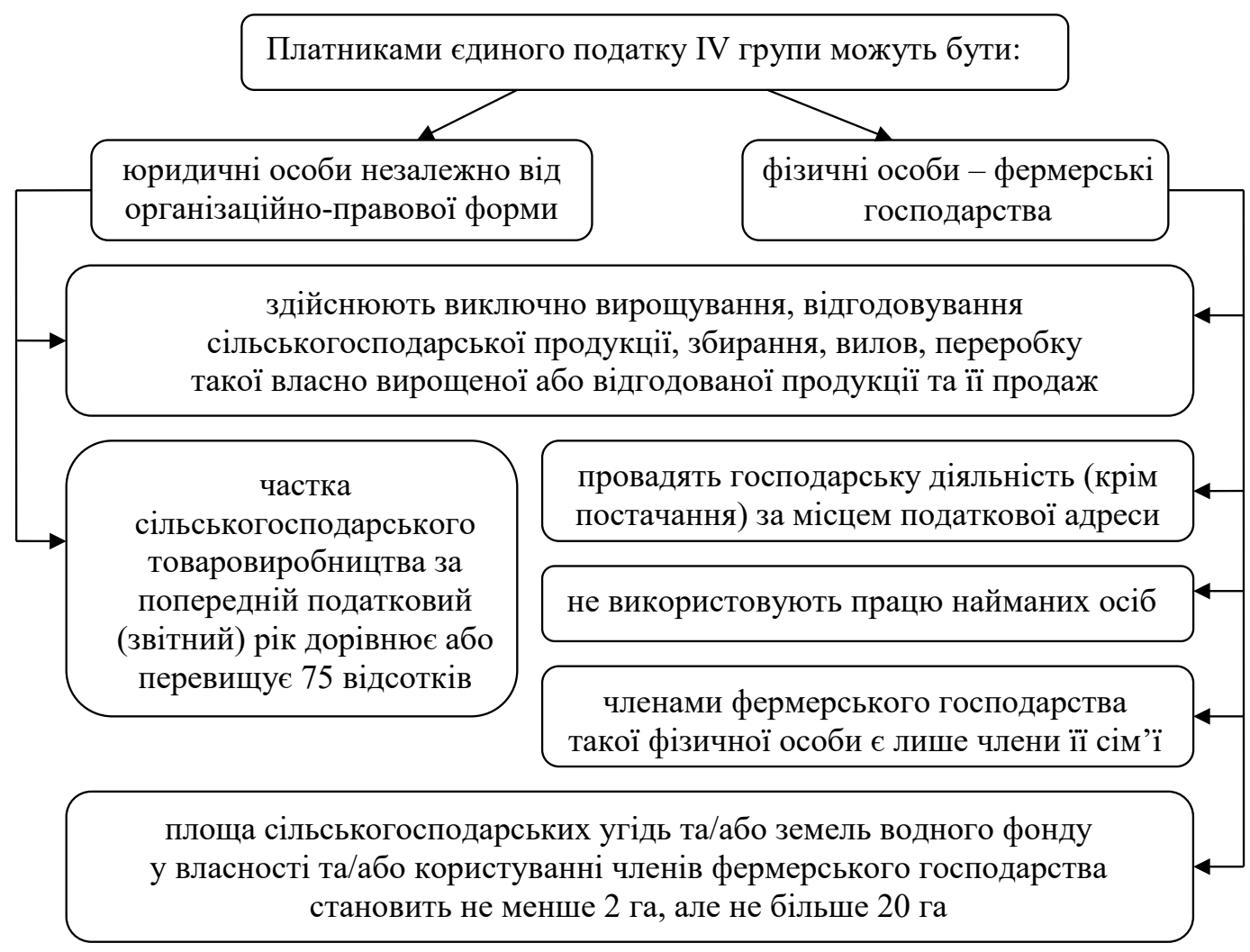

Рис. 1. Вимоги до суб'єктів господарювання в частині єдиного податку IV групи Джерело: побудовано авторами за [6]

Головною особливістю єдиного податку четвертої групи $€$ те, що він сплачується замість цілої низки податків, що супроводжується зменшенням податкового тиску на підприємців, звільняє їх від потреби вести великий податковий облік та економити час. Усі інші податки і збори аграрні підприємства сплачують відповідно до чинного законодавства на загальних підставах.

Для розрахунку єдиного податку IV групи використовується нормативна грошова оцінка 1 га сільськогосподарських угідь (ріллі, сіно- жатей, пасовищ і багаторічних насаджень), а для земель водного фоонду (внутрішніх водойм, озер, ставків, водосховищ) - нормативна грошова оцінка ріллі в області, враховуючи коесріцієнт індексації, визначений станом на 1 січня базового податкового (звітного) року (відповідно до п. 5 підр. 8 розд. XX ПКУ за 2015 та 2017-2023 роки дорівнює 1).

Для платників IV групи розмір ставок податку 31 га с.г. угідь або земель водного фонду залежить від категорії земель, їх розташування (таблиця 1).

Ставки єдиного податку IV групи (станом на 2021 р.)

\begin{tabular}{|l|c|}
\hline \multicolumn{1}{|c|}{ Категорія земель } & Ставка \\
\hline для ріллі, сіножатей і пасовищ & 0,95 \\
\hline $\begin{array}{l}\text { для ріллі, сіножатей і пасовищ, розташованих у гірських зонах та на поліських } \\
\text { територіях }\end{array}$ & 0,57 \\
\hline $\begin{array}{l}\text { для багаторічних насаджень (крім багаторічних насаджень, розташованих у } \\
\text { гірських зонах та на поліських територіях) }\end{array}$ & 0,57 \\
\hline $\begin{array}{l}\text { для багаторічних насаджень, розташованих у гірських зонах та на поліських } \\
\text { територіях }\end{array}$ & 0,19 \\
\hline для земель водного фронду & 2,43 \\
\hline для с.г. угідь, що перебувають у закритому ґрунті & 6,33 \\
\hline
\end{tabular}


Аграрні підприємства - юридичні особи мають самостійно обчислити суму податку щороку за станом на 1 січня. Податкова декларація на поточний рік подається органу державної податкової служби за місцезнаходженням платника податку та місцем розташування земельної ділянки до 20 лютого поточного року. Аграрні підприємства сплачують єдиний податок, перераховуючи в установлений строк загальну суму коштів на відповідний рахунок місцевого бюджету за місцем розташування земельної ділянки. Сплата податку проводиться щоквартально протягом 30 календарних днів, що настають за останнім календарним днем податкового (звітного) місяця. Специсріку сільськогосподарського виробництва відображає саме поквартальна розбивка річної суми податку: I квартал - 10\%; II квартал - 10\%; III квартал - 50\%; IV квартал - 30\%.

Якщо хоча б одна з вимог перебування як фрермерського господарства так і аграрного підприємства - юридичної особи на IV групі платників єдиного податку не відповідає, то такий суб'єкт господарювання може обрати III групу платників єдиного податку і сплачувати податок з одержаного доходу. Але знову ж таки за умови, що протягом календарного року обсяг доходу не перевищує 1167 розмірів мінімальної заробітної плати, встановленої законом на 1 січня податкового (звітного) року (у 2021 р. - 7002000,00 грн). Якщо ж вимоги перебування на єдиному податку III та IV групи не виконуються, то такі суб'єкти господарювання можуть обрати загальну систему оподаткування.

Облік єдиного податку аграрні підприємства ведуть на субрахунку 641 «Розрахунки за податками» в розрізі аналітичного рахунку (субрахунку третього порядку) наприклад, 6411 «єдиний податок». У кінці звітного року суму ЄП 4-ої групи розподіляють між об'єктами обліку витрат продукції рослинництва пропорційно до площі угідь, зайнятих відповідними культурами. Відповідно до діючого Плану рахунків вся інфрормація про ЄП IV групи накопичується на рахунку 91 «Загальновиробничі витрати». Виходячи 3 того, що ЄП IV групи відображають у складі загальновиробничих витрат і база розподілу стосується лише галузі рослинництва, то списання його відбувається на відповідний аналітичний рахунок до субрахунку 231 «Рослинництво», який відкривають до

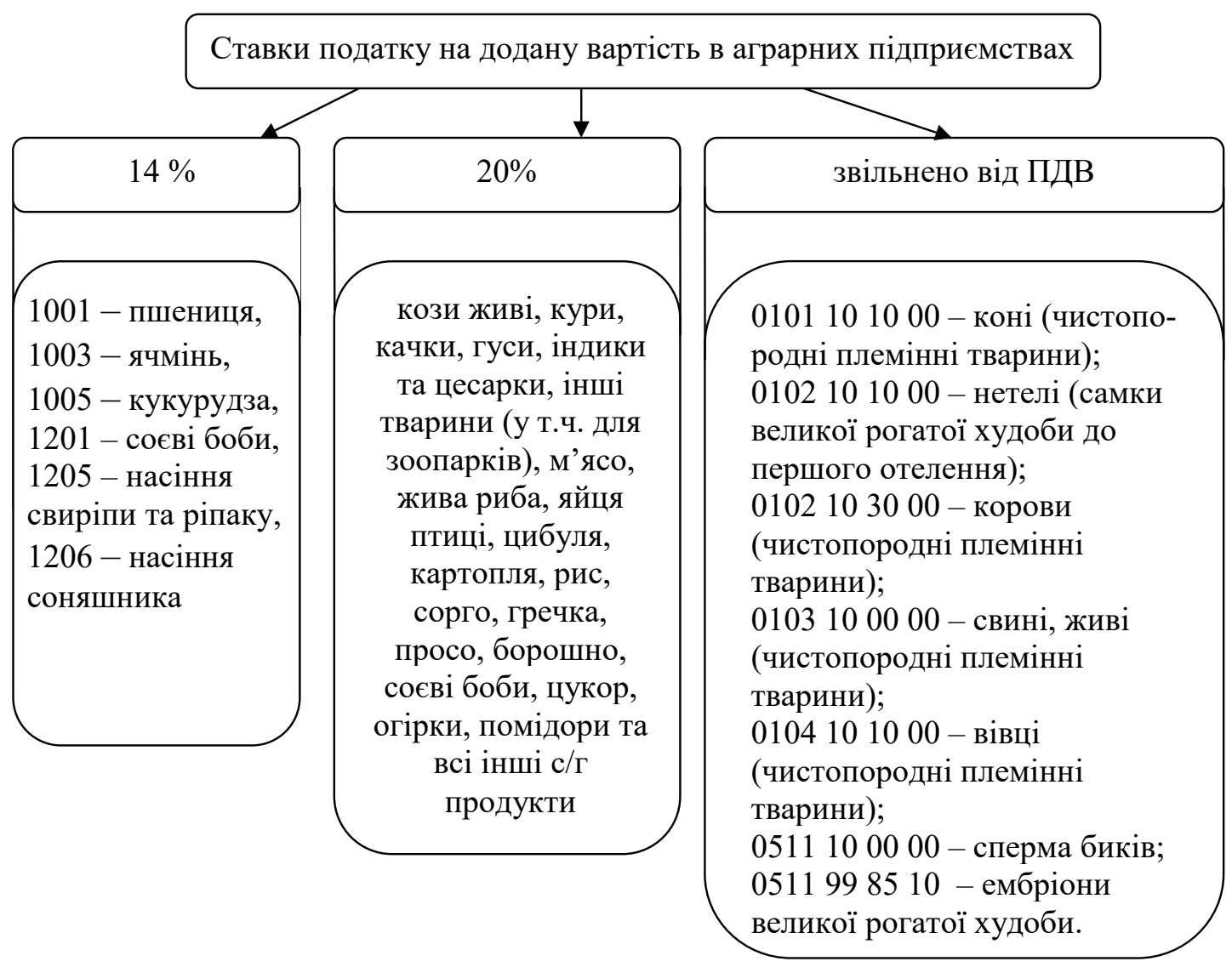

Рис. 2. Ставки податку на додану вартість за окремими товарними позиціями (УКТ ЗЕД) сільськогосподарської продукції 


\section{Особливості облікового відображення розрахунків}

Таблиця 2 за податками в аграрних підприємствах

\begin{tabular}{|c|c|c|c|}
\hline Вид податку & $\begin{array}{c}\text { Особливості } \\
\text { оподаткування }\end{array}$ & $\begin{array}{c}\text { Документальне } \\
\text { забезпечення }\end{array}$ & $\begin{array}{c}\text { Облікове } \\
\text { відображення }\end{array}$ \\
\hline $\begin{array}{l}\text { Єдиний } \\
\text { податок }\end{array}$ & $\begin{array}{l}\text { Платники - аграрні підприєм- } \\
\text { ства (юридичні особи); } \\
\text { фрермерські господарства } \\
\text { (фрізичні особи-підприємці); } \\
\text { замінює сплату деяких податків; } \\
\text { поквартальна розбивка річної } \\
\text { суми податку I квартал - } \\
10 \% ; \text {;I квартал - 10\%; III } \\
\text { квартал - 50\%; IV квартал - } \\
\text { 30\%; } \\
\text { розмір ставок податку } \\
\text { визначається з 1 га с.г. угідь } \\
\text { або земель водного фонду } \\
\text { та залежить від категорії } \\
\text { земель, їх розташування. }\end{array}$ & $\begin{array}{l}\text { Операції з } \\
\text { нарахування податку } \\
\text { відображаються } \\
\text { в бухгалтерській } \\
\text { довідці; } \\
\text { Відомість про } \\
\text { наявність земельних } \\
\text { часток є невід'ємною } \\
\text { частиною податкової } \\
\text { декларації. }\end{array}$ & $\begin{array}{l}\text { Дт 91/ЄП Кт 641/ } \\
\text { ЄП - відображено } \\
\text { нарахування єдиного } \\
\text { податку; } \\
\text { Дт 641/Єп кт } 31 \\
\text { - сплачено суму } \\
\text { єдиного податку до } \\
\text { місцевого бюджету }\end{array}$ \\
\hline $\begin{array}{l}\text { Податок } \\
\text { на додану } \\
\text { вартість }\end{array}$ & $\begin{array}{l}\text { Передбачено спеціальну } \\
\text { ставку } 14 \% \text { на окремі } \\
\text { види сільгосппродукції, } \\
\text { а також звільнення від } \\
\text { ПдВ окремих операцій } \\
\text { сільськогосподарських } \\
\text { товаровиробників з імпорту. }\end{array}$ & \begin{tabular}{|l|} 
Операції з \\
постачання окремих \\
сільськогосподарських \\
товарів можуть бути \\
вказані в податковій \\
накладній одночасно \\
з іншими операціями \\
або в окремій \\
податковій накладній \\
із зазначенням коду \\
ставки 14\%.
\end{tabular} & $\begin{array}{l}\text { Дт 641/ПДВ Кт } \\
\text { 631 - відображено } \\
\text { податковий кредит } \\
\text { Дт 701 Кт 641/ } \\
\text { ПдВ - відображено } \\
\text { податкове } \\
\text { зобов'язання } \\
\text { Дт 641/ПдВ Кт } 315 \text { - } \\
\text { списано узгоджену } \\
\text { суму податкового зобо- } \\
\text { в'язання з електронного } \\
\text { ПдВ-рахунку }\end{array}$ \\
\hline
\end{tabular}

рахунку 23 «Виробництво». Аналітичний облік $€$ Є IV групи у структурі загальновиробничих витрат, як правило, ведеться за місцями виникнення та статтями витрат.

Для сільськогосподарських товаровиробників також $€$ особливості оподаткування податком на додану вартість. Зокрема, в 2021 році Законом № 1115 [7] запроваджено зниження ставки ПДВ для аграріїв з 20\% до 14\%. Ставка ПДВ 14\% розповсюдилася на операції постачання сільськогосподарської продукції на території України та щодо ії імпорту певних кодів УКТ ЗЕД, крім імпорту товарів, визначених у п. 197.18 Податкового кодексу України (далі ПКУ) (пп. «Г» П. 193.1 ПКУ). Інші види сільгосппродукції будуть постачатися як на території України, так й імпортуватися за загальною ставкою - 20\%. Експортуватися уся сільгосппродукція буде за звичайною експортною ставкою 0\%. На послуги аграних підприємств ставкаПДВ 14\% не поширюється (розділ 2 Листа № 5257).

Однак 1 липня 2021 року ВР було прийнято Закон № 1575 про внесення змін до ПКУ. За ним на частину видів сільськогосподарської продукції повертається колишня ставка $20 \%$.
Ці зміни застосовується із 01.08.2021 року. За офріційним поясненнями авторів законопроєкту № 5425-д зміни ставки ПДВ змушувала підприємства переробної галузі підвищувати ціни на власну продукцію, аби покрити різницю, яка виникала внаслідок різних ставок ПДВ, за рахунок власних грошей. Після повернення ставки $20 \%$ у такій же програшній ситуації залишаються інші переробники - по тій продукції, де ставка залишилася 14\% (рис. 2).

На офріційному порталі Державної податкової служби України наведено роз'яснення щодо Порядку заповнення податкової накладної за операціями з постачання окремих сільськогосподарських товарів [8]. Зокрема, серед особливостей складання податкової накладної виділено наступні:

- платник податку може зазначити в податковій накладній операції з постачання окремої сільськогосподарської продукції одночасно 3 іншими операціями, виокремлюючи різні ставки (20\%, 7\% та/або 0\%), або ж сфрормувати окремі податкові накладні;

- в табличній частині податкової накладної (розділ «Б», графра 8) складається за операціями 
з постачання окремої сільськогосподарської продукції потрібно вказати код ставки «14»;

- в табличній частині податкової накладної (розділ «Б», грасра 3.1) за операціями з постачання окремої сільськогосподарської продукції потрібно вказати не менше шести знаків коду УКТ ЗЕД (група кодів УКТ ЗЕД 0104 10, 1204 00, 1206 00,1212 91);

- в податковій накладній в розділі «А» обсяг операцій з постачання окремої сільськогосподарської продукції потрібно вказати в рядку VIII, суму податку - в рядку V, загальну суму податку за ставками ПДВ 20, 14 та 7\% - в рядку II, загальну суму податку за операцією в рядку I [9].

Застосування перерахованих вище особливостей складання податкової накладної за операціями з постачання окремих сільськогосподарських товарів забезпечено ДПС для складання податкової накладної в електронному вигляді, у тому числі і в електронному кабінеті платника податків.

Сума ПДВ відображається на аналітичному рахунку «Розрахунки за податком на додану вартість» до рахунку 641 «Розрахунки 3 податків». При придбанні або виготовленні товарно-матеріальних цінностей фрормується податковий кредит. Продавець, що постачає сільськогосподарську продукцію, нараховує податкові зобов'язання з ПДВ (п. 185.1 ПК). На рахунку 315 «Спеціальні рахунки в національній валюті» обліковують кошти на електронному ПДВ-рахунку, що Казначейство відкриває платникові ПДВ. При застосуванні предоплати застосовуються спеціальні рахунки 643 «Податкові зобов'язання», 644 «Податковий кредит».

Особливості облікового відображення розрахунків за податками в сільськогосподарських підприємствах узагальнено в таблиці 2.

Висновки і перспективи подальших досліджень. Аграрні товаровиробники мають можливості обирати систему оподаткування в залежності від особливостей діяльності. Саме це і зумовлює особливий характер розрахунків за податками, порядок відображення в документальному та обліковому забезпеченні суб'єкта агровиробництва. Виділені особливості обліку розрахунків за податками мають стати основою для побудови есрективної системи менеджменту і розробки напрямків оптимізації податкового навантаження в аграрному виробництві.

\section{СПИСОК ВИКОРИСТАНИХ ДЖЕРЕЛ:}

1. Бурковська А.В., Шкапоєд В.К. Сучасні особливості оподаткування сільськогосподарських підприємств України. Modern Economics. 2017. № 6. С. 24-30. URL: https://modecon.mnau.edu.ua/issue/6-2017/UKR/ burkovskaya.pdf

2. Колеснік Я.В., Ніколаєнко А.В. Оподаткування аграрних підприємств: минулий досвід та реалії сьогодення. Агросвіт. 2018. № 20. С. 37-42. URL: http://www.agrosvit.info/?op=1\&z=2738\&i=5

3. Міньковська А. Особливості оподаткування виробників сільськогосподарської продукції. Обліково-аналітичне, фрінансове та інформаційне забезпечення в системі управління аграрним сектором економіки: теорія і практика : колективна монографія. / за заг. ред. Г.Є. Павлової та Л.М. Васільєвої. Дніпро : АРТ Синтез-Т, 2020. С. 122-129.

4. Міньковська А.В., Горовата О.А. Оподаткування сільськогосподарських підприємств. Збірник матеріалів VIII міжнародної науково-практичної конфреренції «Забезпечення сталого розвитку аграрного сектору економіки: проблеми, пріоритети, перспективи» (м. Дніпро, 26-27 жовтня 2017 р.). Том 1. Дніпро : Друкарня «Стандарт», 2017. С. 16-17.

5. Новак Н.П., Коваль С.В., Круковська О.В. Особливості системи оподаткування сільськогосподарських підприємств в Україні та напрями її вдосконалення з врахуванням зарубіжного досвіду. Економічний вісник університету. 2018. Вип. 39. С. 29-37. URL: http://nbuv.gov.ua/UJRN/ecvu_2018_39_6

6. Податковий кодекс України : Закон України № 2755-VI від 01.08.2021 p. URL: https://zakon.rada.gov.ua/ laws/show/2755-17

7. Про внесення змін до Податкового кодексу України щодо ставки податку на додану вартість 3 операцій з постачання окремих видів сільськогосподарської продукції : Закон України № 1115 від 17.12.2020. URL: https://zakon.rada.gov.ua/laws/show/1115-20\#Text

8. Про затвердження форми податкової накладної та Порядку заповнення податкової накладної : наказ Міністерства фрінансів України від 31.12.2015 p. № 1307. URL: https://zakon.rada.gov.ua/laws/show/z0137-16\#Text

9. Сільгоспвиробники і податкова накладна: Офріційний портал «Державна податкова служба України». URL: https://kyivobl.tax.gov.ua/media-ark/local-news/print-464351.html 


\section{REFERENCES:}

1. Burkovs'ka A.V., Shkapoied V.K. (2017) Suchasni osoblyvosti opodatkuvannia sil's'kohospodars'kykh pidpryiemstv Ukrainy [Modern features of taxation of agricultural enterprises of Ukraine]. Modern Economics, 6, 24-30. Available at: https://modecon.mnau.edu.ua/issue/6-2017/UKR/burkovskaya.pdf (in Ukrainian)

2. Kolesnik Ya.V., Nikolaienko A.V. (2018) Opodatkuvannia ahrarnykh pidpryiemstv: mynulyj dosvid ta realii s'ohodennia [Taxation of agricultural enterprises: past experience and realities of the present]. Ahrosvit, 20, 37-42. Available at: http://www.agrosvit.info/?op=1\&z=2738\&i=5 (in Ukrainian)

3. Min'kovs'ka A. (2020) Osoblyvosti opodatkuvannia vyrobnykiv sil's'kohospodars'koi produktsii [Features of taxation of agricultural producers]. Oblikovo-analitychne, finansove ta informatsijne zabezpechennia $v$ systemi upravlinnia ahrarnym sektorom ekonomiky: teoriia i praktyka: kolektyvna monohrafiia / za zah. red. H.Ye. Pavlovoi ta L.M. Vasil'ievoi. Dnipro: ART Syntez-T, 122-129.

4. Min'kovs'ka A.V., Horovata O.A. (2017) Opodatkuvannia sil's'kohospodars'kykh pidpryiemstv [Taxation of agricultural enterprises]: Zbirnyk materialiv VIII mizhnarodnoi naukovo-praktychnoi konferentsii «Zabezpechennia staloho rozvytku ahrarnoho sektoru ekonomiky: problemy, priorytety, perspektyvy - Ensuring sustainable development of the agricultural sector of the economy: problems, priorities, prospects», Dnipro: Drukarnia «Standart», tom 1, 16-17.

5. Novak N.P., Koval' S.V., Krukovs'ka O.V. (2018) Osoblyvosti systemy opodatkuvannia sil's'kohospodars'kykh pidpryiemstv $v$ Ukraini ta napriamy ii vdoskonalennia z vrakhuvanniam zarubizhnoho dosvidu [Features of the system of taxation of agricultural enterprises in Ukraine and directions of its improvement taking into account foreign experience]. Ekonomichnyj visnyk universytetu, 39, 29-37. Available at: http://nbuv.gov.ua/UJRN/ecvu_2018_39_6 (in Ukrainian)

6. Podatkovyj kodeks Ukrainy vid 01.08.2021 r. № 2755-VI (zi zminamy i dopovnenniamy). Available at: https://zakon.rada.gov.ua/laws/show/2755-17 (in Ukrainian)

7. Pro vnesennia zmin do Podatkovoho kodeksu Ukrainy schodo stavky podatku na dodanu vartist' z operatsij z postachannia okremykh vydiv sil's'kohospodars'koi produktsii: Zakon Ukrainy № 1115 vid 17.12.2020. Available at: https://zakon.rada.gov.ua/laws/show/1115-20\#Text (in Ukrainian)

8. Pro zatverdzhennia formy podatkovoi nakladnoi ta Poriadku zapovnennia podatkovoi nakladnoi: nakaz Ministerstva finansiv Ukrainy vid 31.12.2015 r. № 1307. Available at: https://zakon.rada.gov.ua/laws/show/z0137-16\#Text (in Ukrainian)

9. Sil'hospvyrobnyky i podatkova nakladna: Ofitsijnyj portal «Derzhavna podatkova sluzhba Ukrainy». Available at: https://kyivobl.tax.gov.ua/media-ark/local-news/print-464351.html (in Ukrainian) 